\title{
ANALISIS PESAN DAKWAH SYIIR TANPO WATON PENDEKATAN SEMIOTIK FERDINAND DE SAUSSURE
}

\author{
Mohammad Fajar Amertha \\ STID Al-Hadid, Surabaya \\ m.fajaramertha72@gmail.com
}

\begin{abstract}
Abstrak: Syiir yang diciptakan oleh K.H. Muhammad Nizam As-Shafa (Gus Nizam) ini amat dikenal oleh warga Jawa Timur khususnya Surabaya, selalu diputar di masjidmasjid atau musala setiap kali memasuki waktu azan salat. Syiir yang rutin diperdengarkan sejak tahun 2004 bahkan hingga saat tulisan ini dibuat menggunakan bahasa Arab dan Jawa yang pastinya memiliki makna simbolik dari bahasa yang digunakan. Pada artikel ini mendalami makna yang tersirat pada Syi'ir Tanpa Waton, melalui pendekatan kualitatif, menganalisis pesan dakwah bentuk syiir menggunakan Teori Semiotik Ferdinand de Saussure. Hasil yang didapatkan menunjukkan bahwa Syi'ir Tanpo Waton mengandung pesan dakwah: (1) pesan Ketauhidan dan memberikan penghormatan terhadap Rasul; (2) menghindari sifatsifat manusia yang bertentangan dengan ajaran Islam; (3) untuk senantiasa memuji Allah dan mencari ilmu agama dengan cara yang benar bukan hanya membaca dan menghafalnya saja; (4) Ajakan untuk senantiasa mengkaji ilmu pengetahuan, menguatkan iman dan membangun hati yang luhur. Studi ini juga menunjukkan bahwa terdapat kesesuaian antara parole dan langue; signifie dan signifiant pada penggunaan bahasa Jawa dan Arab sehingga menghasilkan tanda yang khas dan perpaduan rasa dalam ungkapan yang mampu menggugah kesadaran pendengarnya untuk menerapkan pesan yang terkandung di dalamnya.

Kata kunci: Syi'ir Tanpo Waton, analisis semiotik Saussure, semiotik pesan dakwah
\end{abstract}

Analysis of Da'wah Messages Syiir Tanpo Waton Semiotic Approach of Ferdinad De Saussure. Abstract: The Syiir (religious rhyme) created by K.H. Muhammad Nizam As-Shafa (Gus Nizam) is well known by people of East Java, especially people of Surabaya, who always play it in mosques every time the azan prayers come. The Syir, which has been routinely played since 2004 to the time when the research was made, used both Javanese and Arabic. Thus, it must has a symbolic meaning of the language used. This article aims to discover the meaning implied in Syi'ir Tanpo Waton, by using qualitative approach. Data analysis using semiotic theory of structuralist Ferdinand de Saussure. It results that the Syiir contains Dakwah message such as (1) oneness of God and being respectful towards the Prophet; (2) avoid human nature which has contrary to Islam; (3) to always praise in God and learn religious knowledge with the right methods, not only by recitation; (4) Inviting us to always learn science, strengthen our faith, and be kind to others. This study also reveals that there are suitability between langue and parole, signifie and signifiant in Javanese and Arabic used. Thus produce a mixture of sense in utterances that they can revive the listener's consciousness to apply the Da'wah message.

Keywords: Syi'ir tanpo waton, Saussure's semiotic analysis, semiotics of da'wah message 


\section{Pendahuluan}

Pesan dakwah bisa dipahami sebagai seruan untuk mengajak pada kebaikan dan meninggalkan kemungkaran. Seruan kebaikan serta seruan untuk meninggalkan kemungkaran merupakan seruan yang mengajak pada fitrah manusia bahwa manusia senantiasa menginginkan kebaikan serta senantiasa meninggalkan keburukan atau kemungkaran supaya beruntung, Alquran surah Ali Imron ayat 104 mengungkapkan: "Dan hendaklah ada di antara kamu segolongan umat yang menyeru kepada kebajikan, menyuruh kepada yang ma'ruf dan mencegah dari yang munkar merekalah orang-orang yang beruntung." Kebaikan yang menjadi fitrah manusia tersebut dapat mengarahkan pada setiap langkah gerak untuk menggapai kesuksesan tidak hanya dalam dimensi duniawi tetapi juga dimensi ukhrawi. Syi'ir merupakan karya sastra yang memungkinkan berisikan pesan dakwah yang dapat dipahami maknanya dengan berbagai pendekatan. Salah satu pendekatan yang memungkinkan untuk digunakan dalam memahami makna pesan adalah semiotik. Semiotik sebagai salah satu rujukan untuk membantu melacak sebuah coretan yang bermakna tidak hanya sisi material (tulisan) namun juga sisi mental pada penanda tersebut.

Salah satu syi'ir yang sangat dikenal di masyarakat Jawa Timur adalah Syi'ir Tanpo Waton. Syi'ir Tanpo Waton adalah sebuah syi'ir yang dibuat oleh K.H. Muhammad Nizam As-Shofa, Lc. (Pengasuh Pondok Pesantren As-Shofa wal Wafa di Wonoayu Sidoarjo), yang dibuat pertama kali mulai

\footnotetext{
${ }^{1}$ Nikken Derek Saputri, "Syi'ir Tanpa Waton (Kajian Semiotik)," Sutasoma: Journal of Javanese Literature, Vol. 2, no. 1, (2013), 3.
}

tahun 2004 kemudian direvisi tahun 2007 sebab pada syi'ir yang pertama terlalu panjang menurut penuturan beliau. ${ }^{1}$ Hingga sampai saat ini syi'ir ini tetap eksis serta disukai oleh masyarakat. Hal inilah yang menarik untuk diteliti lebih mendalam khususnya pada makna simbolik atas pesan dakwah tersebut. Syi'ir ini menarik karena dikemas dalam bahasa Jawa dan Arab yang tentunya memiliki makna simbolik dari pesan yang terkandung di dalamnya. Sebagai sebuah syi'ir yang diputar di masjidmasjid, syi'ir ini tentunya memilki kandungan pesan dakwah.

Pada umumnya keberadaan karya sastra kurang dikenal atau diketahui masyarakat sekarang. Hal itu disebabkan karya sastra lama menggunakan bahasa daerah yang sulit dipahami masyarakat. Berbeda dengan Syi'ir Tanpo Waton yang familiar di telinga masyarakat, penggunaan bahasa Jawa dan Arab yang mudah dimengerti adalah salah satu alasannya. Meskipun demikian, dibalik kesederhanaan bahasanya diduga terdapat interpretasi atas simbol-simbol teks di dalam Syi'ir Tanpo Waton mengandung makna yang dalam sehingga perlu untuk meneliti dan menganalisis simbol dalam wilayah semiotik.

Fokus pembahasan dalam artikel ini adalah pemahaman pesan dakwah dalam semiotika dengan mengacu pada pendekatan Ferdinand de Saussure yang terdapat pada Syi'ir Tanpo Waton. Pesan dakwah apa yang menonjol dalam syi'ir yang disampaikan Gus Nizam dan bagaimana pesan syi'ir dalam bahasa Arab dan Jawa dikembangkan dengan sebuah model relasi pada tataran 
semiotik. Di sini memahami pesan tidak hanya dalam rangkai bunyi namun juga mempertalikan konsep semiotik pada signifier dan signified yang mampu untuk menumbuhkan rasa dalam jiwa sehingga menggugah penghayatan pada pendengar.

Beberapa penelitian terdahulu yang mengacu pada teori semiotik diantarnya, pertama, penelitian yang dilakukan oleh Chistian K. Wedemeyer berjudul: "Beef, Dog, and Other Mythologies: Connotative Semiotics in Mahayoga Tantra Ritual and Scripture." 2 Penelitian ini memfokuskan pada semiotik konotatif serta tanda-tanda bahasa yang ada dalam Kitab Mahayoga Tantra dari Agama Budha aliran Budha Tantra dengan membandingkan pada tradisi di India mengenai sapi. Fokus penelitian berpijak pada bentuk bahasa dalam sebuah kalimat-kalimat yang terangkai pada kitab Mahayoga dengan pendekatan teori Roland Barthes. Kedua, penelitian yang dilakukan oleh Nikken Derek Saputri berjudul Syi'ir Tanpa Waton (Kajian Semiotik). ${ }^{3}$ Penelitian ini lebih melihat pada semantik makna dalam simbol pesan Syi'ir Tanpo Waton dengan pendekatan teori semiotik Teeuw.

Berdasarkan beberapa studi terdahulu maka belum ada studi yang menganalisis dengan pendekatan teori semiotika strukturalis Saussure, yang menggali makna melalui langage dan sign dengan memadukan pemaknaan pada simbol Jawa dan simbol Arab. Di antara kedua studi sebelumnya juga belum terdapat fokus penelitian yang menggali pesan dakwah yang terkandung dalam suatu syi'ir melalui pendekatan

2 Christian K. Wedemeyer, "Beef, Dog, and Other Mythologies: Connotative Semiotics in Mahayoga Tantra Ritual and Scripture," Journal of the American Academy of Religion, Vol. 75, no. 2, 2007, 383-417 semiotik strukturalis, spesifiknya Syi'ir Tanpo Waton. Sehingga studi ini nantinya dapat bermanfaat bagi pengembangan ilmu dakwah khususnya pada analisis makna tanda-tanda dalam pesan dakwah.

Metode studi ini didasarkan pada penelitian kualitatif. Studi ini berfokus pada ungkapanungkapan Syi'ir Tanpo Waton dengan melakukan analisis interpretasi atas simbolsimbol menggunakan teori Semiotik Strukturalisme Ferdinand de Saussure yang berusaha untuk menguak tanda atas seluruh simbol dalam syi'ir tersebut yang belum dijawab dengan pendekatan semiotik, khususnya pada aspek simbol kata yang tertulis dalam perpaduan bahasa Jawa dan Arab. Sehingga akan tergambar secara integral makna interpertasi syi'ir tersebut. Untuk itu diperlukan upaya pemahaman semiotik dengan sistem analisis tanda dengan melakukan rekonstruksi maupun dekonstruksi. ${ }^{4}$

\section{Syi'ir Tanpo Waton}

Syi'ir Tanpo Waton adalah syi'ir yang berkembang di tanah Jawa ditulis oleh KH. Mohammad Nizam As-Shafa, Lc. pengasuh Pondok Pesantren Ahlus Shafa wal Wafa Simoketawang, Wonoayu, Sidoarjo. Karakter ragam bahasa yang digunakan adalah perpaduan antara bahasa Arab dan bahasa Jawa. Karakter ini menunjukkan bahwa syi'ir tersebut ditujukan pada tataran komunikasi pesan yang didasarkan atas etnografis tertentu atau sosial tertentu yang

\footnotetext{
3 Saputri, "Syi'ir Tanpo.," 3

4 Suwardi Endaswara, Metodologi Penelitian Sastra Epistemologi, Model, Teori dan Aplikasi (Yogyakarta:CAPS, 2013), 45.
} 
tentunya memiliki speech komunikasi yang sama. $^{5}$

Syi'ir Tanpo Waton ini terdiri atas enam belas bait syi'ir dengan gabungan menggunakan bahasa Jawa dan bahasa Arab. Tiga belas bait syi'ir menggunakan bahasa Jawa sedang tiga bait syi'ir menggunakan bahasa Arab. Tanpo dalam bahasa Jawa diartikan tanpa. ${ }^{6}$ Adapun waton diartikan asal, pedoman. ${ }^{7}$ Sehingga Syi'ir Tanpo Waton jika ditinjau dari pengertiannya bermakna syi'ir tanpa asal atau syi'ir tanpa pedoman. Syi'ir Tanpo Waton juga berarti syi'ir tanpa batas. Makna tanpa batas menunjukkan bahwa syi'ir tersebut dapat melewati batas zaman sebab istilah batas biasanya disandarkan pada suatu tempat atau waktu.
Menurut pengakuan Gus Nizam Syi'ir Tanpo Waton dibuat ketika beliau melakukan khalwat selama dua minggu sebagai tradisi yang ada dan dikembangkan di dalam keluarga beliau. Adapun makna khalwat ( memiliki arti mengasingkan diri. ${ }^{8}$ Pada awalnya penyebaran syi'ir tersebut terbatas pada kalangan jemaah saja dan kalangan mereka yang mengaji pada Gus Nizam. Selanjutnya syi'ir tersebut disebarkan oleh Radio Yasmara (Yayasan masjid Rahmat) dan diperdengarkan setiap menjelang salat lima waktu. Saat syi'ir tersebut diperdengarkan pertama kali kebanyakan orang mengira bahwa yang melantunkan syi'ir tersebut adalah Gus Dur. ${ }^{9}$ Sehingga syi'ir tersebut menjadi booming dan dikenal oleh banyak masyarakat khususnya masyarakat muslim. ${ }^{10}$ Sampai saat ini sasaran bunyi syi'ir tersebut ditujukan pada objek masyarakat muslim awam. Bunyi Syi'ir Tanpo Waton adalah sebagai berikut: ${ }^{11}$

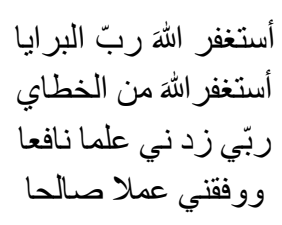

$$
\begin{aligned}
& \text { يارسولَ اللهِ سلامٌ عليكَ } \\
& \text { يار بيحَ الثنّان و الدّرج } \\
& \text { عطفة ياجيرة العلِِ } \\
& \text { يبااهيلَ الجودِ و الكرجِ }
\end{aligned}
$$

\author{
(Literasi huruf latin - Bait ke-1) \\ Astagfirullaha rabba bara'ya \\ Astagfirullaha mina al khataya \\ Rabby zidny 'ilmaan naafi'an \\ Wawafignyi 'amalan shaalikhann \\ (Terjemahannya) \\ Aku memohon ampun ya Allah \\ Maha Penerima Taubat \\ Aku memohon ampun ya Allah \\ dari segala dosa \\ Tambahkanlah kepadaku ilmu \\ yang bermanfaat \\ Berikanlah aku amalan yang baik
}

\author{
(Bait ke-2) \\ Yaa Rasullulahi Salaamunn \\ alaikaa \\ Yaa Rafii Assya'ni waddarajii \\ Athfataa yaa jiirathal aalaami \\ Yaa unaila al juudi wa al karami \\ (Terjemahannya) \\ Wahai utusan Allah, semoga \\ keselamatan tetap padamu \\ Wahai yang berbudi luhur dan \\ bermartabat tinggi \\ Rasa kasihmu wahai pemimpin \\ tetangga/lingkungan sekitar
}

\footnotetext{
5 Engkus Kuswarno, Metode Penelitian Komunikasi Etnografi Komunikasi (Bandung: Widia Padjajaran, 2011), 39.

6 Majendra Maheswara, Kamus Jawa Indonesia (Yogyakarta:Pustaka Mahardika, tt), 309.

7 lbid, 337.

8 A.W. Munawir, Muhammad Fairus, Kamus AlMunawir Indonesia-Arab (Surabaya:Pustaka Progresif, 2007), 442.
}

9 Beliau adalah mantan ketua PBNU dan mantan Presiden Republik Indonesia.

${ }^{10}$ Surat Kabar Harian Bangsa, Jum'at 19 Agustus 2011, 1.

${ }^{11}$ Gus Nizam, "Syi'ir Tanpo Waton," Surat kabar Media Umat, Minggu ke III dan Ke IV 2014, 16 Rajab-Sy'ban $1435 \mathrm{H}$, bait-1 
Wahai ahli dermawan dan pemurah hati

\section{(Bait ke-3)}

Ngawiti ingsun nglaras syi'iran

Kelawan muji maring Pengeran

Kang paring rohmat lan

kanikmatan

Rina wengine tanpa petungan $2 x$

(Terjemahannya)

Aku awali melantunkan syair

Dengan memuji kepada Tuhan

Yang memberi rahmat dan

kenikmatan

Siang dan malam tanpa

perhitungan

\section{(Bait ke-4)}

Dhuh bala kanca priyo wanito

Aja mung ngaji syare'at bloko

Gur pinter ndongeng nulis lan

moco

Tembe mburine bakal sengsoro

$2 x$

(Terjemahannya)

Wahai, para teman pria wanita

Jangan hanya belajar syariatnya

saja

Hanya akan pandai berbicara,

menulis dan membaca

Baru belakangan akan sengsara

\section{(Bait ke-5)}

Akeh kang apal Qur'an Haditse Seneng ngafirke marang liyane Kafire dhewe dak digatekke Yen isih kotor ati akale $2 x$

(Terjemahannya)

Banyak yang hafal Al Qur'an dan Hadisnya

Senang mengafirkan orang lain

Kafirnya sendiri tidak dihiraukan Jika masih kotor hati dan

pikirannya

\section{(Bait ke-6)}

Gampang kabujuk nafsu angkara Ing pepahese gebyare ndonya Iri lan meri sugihe tanggo

Mula atine peteng lan nistho $2 x$
(Terjemahannya)

Mudah terbujuk nafsu angkara

Dalam gemerlapnya hiasan dunia

Iri dan dengki dengan kekayaan

tetangga

Sehingga hatinya gelap dan nista

(Bait ke-7)

Ayo sedulur ja nglalekake

Wajibe ngaji sak pranatane

Nggo ngandelake iman tauhide

Baguse sangu mulya matine

(Terjemahannya)

Ayo saudara jangan melupakan

Wajibnya mengkaji beserta

aturannya

Untuk mempertebal iman

tauhidnya

Bagusnya bekal mulia matinya

\section{(Bait ke-8)}

Kang aran sholeh bagus atine

Kerana mapan sari ngelmune

Laku thariqot lan ma'rifate

Uga haqiqot manjing rasane

(Terjemahannya)

Yang disebut sholeh adalah yang

hatinya bagus

Karena sudah lengkap ilmunya

Jalan Tarikat dan makrifatnya

Hakikat juga meresap pada

perasaannya

\section{(Bait ke-9)}

Al Qur"an qodim wahyu minulya

Tanpa tinulis iso diwoco

Iku wejangan guru waskitho

Den tancepake ing njero dhodho

(Terjemahannya)

Al Qur'an qodim wahyu mulia

Tanpa ditulis bisa dibaca

Itu nasehat guru yang pintar,

bijaksana

Supaya ditanamkan di dalam dada

\section{(Bait ke-10)}

Kumantil ati lan pikiran

Mrasuk ing badan kabeh jeroan

Mu'jizat rasul dadi pedhoman
Minangka dalan manjinge iman

(Terjemahannya)

Melekat di hati dan pikiran

Merasuk di seluruh badan dan

hati

Mukjizat rasul jadi pedoman

Sebagai sarana masuknya iman

\section{(Bait ke-11)}

Kelawan Allah kang Maha Suci

Kudu rangkulan rina lan wengi

Ditirakati diriyadlohi

Dikir lan suluk ja nganti lali

(Terjemahannya)

Kepada Allah yang Maha Suci

Harus mendekatkan diri siang dan

malam

Diusahakan dengan sungguh dan

ikhlas

Zikir dan suluk jangan pernah lupa

\section{(Bait ke-12)}

Uripe ayem rumangsa aman

Dununge rasa tandha yen iman

Sabar narima najan pas-pasan

Kabeh tinakdhir saking Pengeran

(Terjemahannya)

Hidupnya tentram merasa aman

Mantabnya rasa pertanda

beriman

Sabar menerima meskipun pas-

pasan

Semua takdir dari Pangeran

(Tuhan)

\section{(Bait ke-13)}

Kelawan kanca dulur lan tangga Kang padha rukun aja daksiya Iku sunnahe rasul kang mulya Nabi Muhammad panutan kito

(Terjemahannya)

Kepada teman, saudara, dan

tetangga

Rukunlah dan jangan saling

bertengkar

Itu sunnahnya Rasul yang mulia

Nabi Muhammad Panutan kita 
(Bait ke-14)

Ayo nglakoni sekabehane

Allah kang bakal ngangkat

drajate

Senajan ashor tata dhohire

Ananging mulya maqom drajate

(Terjemahannya)

Ayo lakukan semuanya

Allah yang akan mengangkat

derajatnya

Meskipun rendah tampilan

zahirnya

Namun mulia maqam derajatnya
(Bait ke-15)

Lamun palastra ing pungkasane

Ora kesasar roh lan sukmane

Den gadhang Allah suwarga

manggone

Utuh mayite uga ulese

(Terjemahannya)

Meskipun akhirnya meninggal

Ruh dan sukmanya tidak tersesat

Dirindukan Allah ditempatkan di

surga

Utuh jenazahnya juga kafannya

\section{(Bait ke-16)}

يا رسولَ اللهِ سلامُ عليكَ

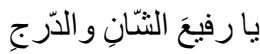

عطفة ياجيرة العلم

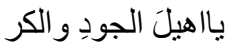

\section{Semiotika Sastra}

Studi semiotika mengacu pada studi umum tentang sistem simbolis, termasuk bahasa juga. Semiotika mengacu pada beberapa topik yang menjadi objek sasaran pembahasan yaitu pertama sintaksis atau studi abstrak tentang tanda dan kaitannya. ${ }^{12}$ Kedua; semantik atau studi tentang hubungan di antara tanda dan objek yang diaplikasikan; dan pragmatik yaitu hubungan antara pengguna dan sistem tanda. ${ }^{13}$ Dalam studi komunikasi semiotika dapat dipahami sebagai tanda (signs) dan simbol yang merupakan tradisi penting dalam pemikiran tradisi komunikasi. ${ }^{14}$ Tradisi semiotik mencakup teori utama mengenai bagaimana tanda mewakili objek, ide, situasi, keadaan, perasaan, dan sebagainya yang berada diluar diri. ${ }^{15}$

Adapun konsep dasar yang menyatukan tradisi semiotika dalam komunikasi adalah "tanda" yang memiliki arti a stimulus designating something other than itself.

\footnotetext{
12 Simon Blacburn, Kamus Filsafat, diterjemahkan oleh Yudi Santoso, (Jakarta: Penerbit Kencana, 2013), 794. 13 Ibid., 794.

${ }^{14}$ Morissan, Teori Komunikasi Individu hingga Massa (Jakarta: Kencana Prenada Media Group, 2013), 32.
}

Atau ilmu tentang tanda, memaknai tanda, memaknai simbol, memaknai analogi, metafora, atau konstruksi makna yang terkandung dalam tanda tersebut. Teori tentang tanda yang menggagas pertama kali adalah filosof dari abad kesembilan belas yaitu Charles Sanders Peirce serta Ferdinand de Saussure walaupun keduanya memiliki paradigma yang berbeda. ${ }^{16}$

Semiotik sastra dalam pengertiannya yaitu konsep yang mempelajari mengenai tandatanda dan lambang-lambang secara struktural dan sistematis dalam sistem tanda sekunder. ${ }^{17}$ Semiotika dapat dijadikan sebuah pendekatan dalam melakukan analisis karya sastra. Seperti yang kita ketahui sebuah karya sastra dapat menyajikan tanda-tanda yang dapat dilihat dari pemakaian bahasa yang digunakan. Pada saat membaca, seseorang akan menginterpretasikan dengan cara yang berbeda berdasarkan pemahaman pembaca tersebut. Namun, semua itu dapat dibatasi

\footnotetext{
15 Ibid., 32.

16 Ibid., 33

17 Jan van Luxemburg dkk, Pengantar Ilmu Sastra diterjemahkan oleh Dick Hartono, (Jakarta: Gramedia, 1992), 45.
} 
oleh adanya pemahaman dalam konvensi bahasa, sastra, dan budaya.

\section{Semiotika Ferdinand de Saussure dalam Teori Strukturalisme}

Kata struktur dapat diartikan dengan kaitankaitan yang tetap dan teratur antara kelompok-kelompok gejala. ${ }^{18}$ Adapun strukturalisme merujuk pada suatu gerakan intelektual yang berpusat di Perancis di tahun 1960-an memahami bahwa fenomena hidup manusia tidak dapat dipahami kecuali adanya saling keterhubungan antar mereka dan hubungan ini membentuk struktur. ${ }^{19}$ Dalam pengertian lain strukturalisme adalah suatu cara berpikir yang memandang suatu realitas (al maujud) sebagai suatu keseluruhan yang terdiri dari strukturstruktur yang saling berkaitan meliputi transformasi, keutuhan, maupun pengaturan diri dalam sistem itu. ${ }^{20}$ Bagi kaum strukturalis manusia digambarkan sebagai hasil struktur-struktur, tidak digambarkan sebagai pencipta struktur, pemikiran ini berlawanan dengan aliran eksistensialisme yang menganggap bahwa manusia itu bebas. ${ }^{21}$ Dalam hal tersebut Ferdinand de Saussure memandang bahwa struktur semacam itu sebagai institusi sosial yang berjangka panjang dengan demikian hubungan antara bahasa dengan realitas sifatnya adalah arbiter. $^{22}$

\footnotetext{
${ }^{18}$ Asep Ahmad Hidayat, Filsafat Bahasa Mengungkap Hakekat Bahasa, Makna dan Tanda (Bandung: Rosdakarya, cet-2, 2009), 102.

${ }^{19}$ Blacburn, Kamus Filsafat., 838.

20 Ibid., 102

21 Hidayat, Filsafat Bahasa., 103.

22 Marianne W Jorgensen dan Louise J.Philips, Analisis Wacana Teori dan Metode, diterjemahkan oleh Imam Suyitno dkk (Yogyakarta:P ustaka Pelajar, 2007), 19.
}

Strukturalisme pertama kali berpijak pada pandangan Saussure yang berkaitan dengan strukturalisme di bidang linguistik. Bahasa menurut Saussure tak hanya sebagai karya musik dalam sebuah permainan simfoni yang utuh bahwa ia terdiri atas unsur parole (ucapan manusia) serta hubungan jaringan "sinkronis" yaitu hubungan antara bunyi dan makna. Baginya bahasa adalah sebuah keutuhan yang berdiri sendiri. ${ }^{23}$ Sehingga dapat dikatakan bahwa Saussure adalah pelopor pada pengembangan konsep teori strukturalisme dalam bidang ilmu pengetahuan lain semisal oleh Claude Levistrauss dalam bidang ilmu antropologi budaya dan M. Foucault dalam sejarah kebudayaan. $^{24}$

Konsep yang dikembangkan oleh Saussure berpijak pada distingsi-distingsi yang diintrodusir dalam strukturalisme, yaitu signifiant dan signife, kemudian langage, parole dan langue, syntagmatic, dan associative/paradigmatic, serta synchronic dan diachronic. ${ }^{25}$ Gagasan tersebut lahir dalam sebuah tulisan karya buku yang berjudul Course de Linguistique Generale ${ }^{26}$ yang membuatnya terkenal di sejumlah ilmuwan terkemuka dalam bidang linguistik.

Penelitian ini hanya dibatasi pada aspek parole dan langue serta signifiant dan signifie yang ditujukan pada pesan dakwah dalam bentuk sastra ini sebab pada bentuk pesan dakwah Syi'ir Tanpo Waton lebih ditekankan pada sisi teks serta kesesuaian

23 Kaelan M.S, Filsafat Bahasa Semiotika dan Hermeneutika, (Yogyakarta: Paradigma, 2009), 182.

24 Ibid., 103.

25 K.Bertens, Filsafat Barat abad XX jilid II Perancis, (Jakarta: Gramedia, 1985), 381.

${ }^{26}$ Alex Sobur, Semiotika Komunikasi (Bandung:Remaja Rosda Karya, 2004), 45. 
dari beberapa bentuk kalimat tersebut dalam pesan dakwah sehingga lebih berkesesuaian jika digali pada aspek langage dan sign dalam konsep semiotika Saussure.

\section{Langage, Parole, dan Langue}

Langage adalah suatu kemampuan bahasa yang ada pada setiap manusia bersifat bawaan yang harus ditunjang dengan lingkungan dan stimulus. ${ }^{27}$ Dalam istilah sederhananya langage berkaitan dengan istilah fenomena bahasa secara umum. ${ }^{28}$ Sebagai contohnya orang Indonesia maka dia berbahasa Indonesia sebab stimulus lingkungan Indonesia-lah yang menyebabkan demikian, begitupula dengan orang Arab ataupun orang Perancis dan selainnya. Fenomena tersebut itulah yang dikatakan dengan langage.

Langue dalam istilah filsafat dikatakan sebagai upaya umum untuk memahami hubungan komponen-komponen bahasa yang digunakan antara pembicara dengan hubungan realitas lain. ${ }^{29}$ langue merupakan sebuah sistem atau dianggap sebagai sebuah sistem, sehingga bahasa adalah langue..$^{30}$ Dalam pengertian umum bisa juga dikatakan langue adalah abstraksi dan artikulasi bahasa pada tingkat sosial dan budaya. ${ }^{31}$ langue dapat pula dikatakan atau disebut sebagai totalitas dari kumpulan fakta atau bahasa. ${ }^{32}$ Sebagai bahasa tentunya dipakai juga dalam hal komunikasi khususnya komunikasi verbal. Sebagai alat komunikasi verbal langue dapat juga

\footnotetext{
27 Kaelan, Filsafat Bahasa., 187.

28 Bertens, Filsafat Barat., 383.

29 Blacburn, Kamus Filsafat., 487.

30 Bertens, Filsafat Barat., 383.

${ }^{31}$ Kaelan, Filsafat Bahasa., 187.

32 Chaedar. A. Alwasilah, Madhab dan Dikotomi Teori Linguistik, (Bandung:Angkasa, 1985), 23.

33 Abdul Chaer, Linguistik Umum, (Jakarta: Rineka Cipta, 2002), 347.
}

dipahami sebagai keseluruhan tanda dalam satu sistem komunikasi verbal antar para anggota suatu masyarakat bahasa namun bersifat abstrak. ${ }^{33}$

Marianne W. Jorgensen mengungkapkan bahwa langue adalah struktur bahasa, yaitu jaringan tanda-tanda yang memberi makna satu sama lain dan strukturnya tetap sifatnya. ${ }^{34}$ Objek studi langue adalah sistem atau tanda atau kode, lebih bersifat kolektif dan pemakaiannya tidak disadari oleh pengguna yang bersangkutan..$^{35}$ Unit dasar langue adalah kata yang bersifat sinkronik dalam arti tanda itu bersifat baku sehingga mudah disusun sebagai suatu sistem. ${ }^{36}$ Dengan demikian dapat dipahami bahwa langue juga sebagai suatu institusi sosial yang otonom yang tidak dicipta melainkan sebagai satuan kontrak dalam sistem tanda yang kolektif serta sungguh-sungguh harus dipatuhi dalam berkomunikasi menggunakan bahasa dengan tanda tersebut. Secara sederhananya dapat dipahami bahwa langue merupakan suatu sistem tanda yang mengungkapkan gagasan. ${ }^{37}$

Adapun parole secara istilah diartikan sebagai suatu pemakaian atau realisasi langue oleh masing-masing anggota masyarakat bahasa sifatnya konkret sebab dia adalah realitas fisis yang berbeda antara orang yang satu dengan orang yang lain. ${ }^{38}$ Parole dapat dipahami juga sebagai bagian bahasa yang sepenuhnya bersifat individual

\footnotetext{
${ }^{34}$ Mariane W Jorgensen dan Louise J.Philips, Analisis Wacana Teori dan Metode, diterjemahkan oleh Imam Suyitno dkk. (Yogyakarta: Pustaka Pelajar, 2007), 19.

${ }^{35}$ Kaelan, Filsafat Bahasa., 189.

36 Ibid., 189.

${ }^{37}$ Ferdinand de Saussure, Pengantar Linguistik Umum, diterjemahkan oleh Rahayu S Hidayat, (Yogya: Gajah Mada University Press, 1988), 82.

38 Ibid., 347.
} 
misalnya : bunyi, realisasi aturan-aturan, ataupun kombinasi tanda. Parole merupakan susunan tanda-tanda yang identik serta senantiasa berulang sebab terkait pada tindakan-tindakan individu serta sebuah mekanisme psikofisik yang dituangkan dalam sebuah bunyi. ${ }^{39}$
Dalam hal tersebut parole merupakan penggunaan bahasa berdasarkan situasi, tanda yang benar-benar digunakan dalam bunyi dengan memahami situasi tertentu dan parole harus didasarkan pada langue. ${ }^{40}$ Untuk lebih mudah memahami antara langue dan parole maka disini akan ditunjukkan perbedaannya:

Tabel 1 - Perbedaan Language dan Parole

\begin{tabular}{l|l}
\hline \multicolumn{1}{c|}{ Langue } & \multicolumn{1}{c}{ Parole } \\
\hline $\begin{array}{l}\text { 1. Polanya kolektif, dimiliki bersama oleh semua } \\
\text { penutur, jadi dapat diungkapkan dengan rumus: } \\
(1+1+1+1+1+1 \ldots)=1\end{array}$ & $\begin{array}{l}\text { 1. Bukanlah sesuatu yang kolektif semua } \\
\text { perwujudannya, bersifat sesaat dan } \\
\text { heterogen dan merupakan perilaku pribadi. } \\
\text { Dapat diungkapkan dengan rumus: } \\
\left(1+1^{\prime}+1^{\prime \prime}+1^{\prime \prime \prime} \ldots\right)\end{array}$ \\
$\begin{array}{l}\text { 2. Berada dalam bentuk keseluruhan kesan yang } \\
\text { tersimpan dalam otak, menyerupai kamus dan ada } \\
\text { pada setiap orang, sama untuk semua orang, tetapi } \\
\text { tidak terpengaruh oleh penyimpanannya. }\end{array}$ & $\begin{array}{l}\text { 2. Sebagai perbuatan bertutur. Selamanya } \\
\text { bersifat perorangan, bervariasi, berubah- } \\
\text { ubah, dan mengandung banyak hal baru. Di } \\
\text { dalamnya tidak ada kesatuan sistem. }\end{array}$ \\
$\begin{array}{l}\text { 3. Produk sosial dari kemampuan bahasa dan sekaligus } \\
\text { merupakan konvensi yang dipengaruhi oleh } \\
\text { kelompok sosial untuk memungkinkan } \\
\text { mempergunakan kemampuan itu. Dan perangkat } \\
\text { konvensi yang siap pakai. }\end{array}$ & $\begin{array}{l}\text { 3. Banyak sekali kombinasi-kombinasi baru pada } \\
\text { setiap pengucapan sehingga sulit untuk dikaji } \\
\text { secara ilmiah. }\end{array}$ \\
$\begin{array}{l}\text { 4. Tanda yang dibangun merupakan benda pasif. } \\
\text { 4. Tanda yang dibangun merupakan benda aktif. }\end{array}$ \\
\hline
\end{tabular}

\section{Signifiant dan Signife}

Ferdinand de Saussure mengungkapkan suatu teori bahwa setiap tanda atau tanda linguistik dibentuk dua komponen yang tidak dapat dipisahkan yaitu komponen signifiant dan signife. ${ }^{41}$ Signife (penanda) dan signifiant (petanda) keduanya merupakan prinsip yang menunjukkan bahwa bahasa adalah sistem tanda (sign) dan setiap tanda itu tersusun atas bagian keduanya. ${ }^{42}$

${ }^{39}$ Kaelan, Filsafat Bahasa., 190.

40 Jorgensen dan Philips, Analisis Wacana., 20.

${ }^{41}$ Chaer, Linguistik Umum., 348.
Suara binatang, suara manusia, atau bunyibunyian hanya bisa dikatakan sebagai fungsi bahasa bila hal tersebut mengekspresikan, menyampaikan ide, atau mengungkapkan hal-hal tertentu berupa pengertian serta harus merupakan bagian sebuah sistem konvensi kesepakatan dan merupakan bagian dari sistem tanda. ${ }^{43}$

Suatu penanda tanpa petanda tidak berarti apa-apa dan karena itu tidak disebut tanda sebaliknya suatu petanda tidak mungkin

\footnotetext{
42 Kaelan, Filsafat Bahasa., 183.

43 Ibid., 183.
} 
disampaikan atau ditangkap lepas dari penanda. Dengan demikian bisa dipahami bahwa penanda dan petanda merupakan kesatuan. $^{44}$

Signifiant bisa dipahami sebagai unsur material dalam bahasa berupa tanda yaitu bunyi tertentu dalam bahasa lisan, coretan grafis dalam bahasa tertulis. Sedangkan signife suatu unsur mental berupa konsep atau anggitan. ${ }^{45} \mathrm{Jadi}$ signife adalah aspek mental dari bahasa. ${ }^{46}$ Sedang hubungan keduanya yaitu signife dan signifiant bersifat arbiter bukan natural demikian pendapat Saussure. ${ }^{47}$ Dalam bahasa sederhana signifie sama dengan "makna" dan signifient sama dengan bunyi bahasa dalam urutan fonemfonem tertentu dan hubungan mereka sangat erat. ${ }^{48}$

Dari beberapa uraian yang dikemukan tersebut dapat dipahami bahwa basis paradigma tanda (sign) dalam teori Saussure berpijak pada pemahaman bahwa tanda (sign) tersusun dari signifie (makna) dan signifiant (bunyi atau unsur material bahasa) sedang keduanya tidak dapat dipisahkan dan memiliki ciri, yang pertama, kesemenaan tanda bahwa tanda dan penanda atau signife dan signifiant memiliki sifat arbiter pada keduanya yang melembaga dalam masyarakat. Kedua, linier yaitu bahwa antara signifie dan signifiant memiliki konsekuensi segaris atau sejalan dalam pemaknaan atas tanda tersebut. ${ }^{49}$ Untuk memahami atas konsep tersebut maka disajikan mengenai bagan yang dikemukakan oleh Ogden dan Palmer sebagai berikut:

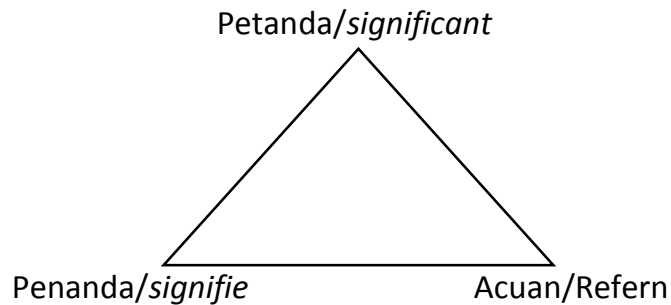

Gambar 1 - Teori Ferdinand de Saussure. ${ }^{50}$

Bagan operasionalisasi konsep semiotik strukturalis Saussure dalam analisis Syi'ir Tanpo Waton:

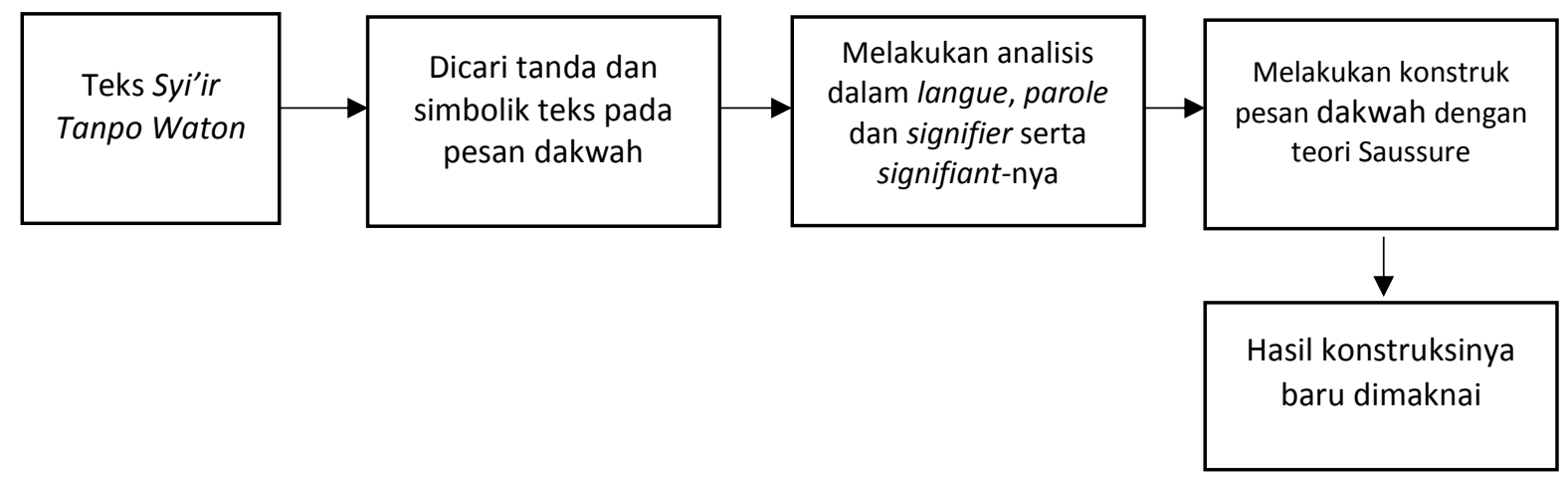

Gambar 2 - Bagan Operasionalisasi Konsep

\footnotetext{
${ }^{44}$ Sobur, Semiotika Komunikasi., 47.

${ }^{45}$ Hidayat, Filsafat Bahasa., 110.

${ }^{46}$ Bertens, Filsafat Barat., 382.

47 Ibid., 382.
}

\footnotetext{
48 Chaer, Linguistik Umum., 348.

${ }^{49}$ Saussure, Pengantar Linguistik., 149-150.

50 Okke K.S. Zaimar, Semiotika Dalam Analisis Karya Sastra (Depok: Komodo Baokks, 2014), 14.
} 


\section{Pesan Dakwah Dalam Syiïr Tanpo Waton Ditinjau dari Semiotika Ferdinand de Saussure}

Studi ini mengkaji content (pesan dakwah) Syi"ir Tanpa Waton. Istilah content dapat dipahami sebagai isi atau materi yang terdapat dalam bentuknya. ${ }^{51}$ Untuk mengkaji content dalam syi'ir tersebut akan digunakan teori semiotik Saussure yang menggolongkan content (isi) menjadi dua jenis tanda, yaitu langue dan parole; signifie dan signifiant. Langue (sistem bahasa) adalah abstraksi dan artikulasi bahasa pada tingkat sosial budaya. Adapun parole merupakan ekspresi bahasa pada tingkat individu. Jika langue memiliki objek studi sistem tanda atau sistem kode sedang unit dasar langue adalah kata maka parole yaitu bahasa yang hidup sebagaimana dalam penggunaannya maka unit dasar parole adalah kalimat. Langue dan parole keduanya tidak bisa dipisahkan sebab merupakan satu unit sistem bahasa. Tidak mungkin ada langue tanpa parole. Sebagai contoh, bahasa tertulisnya adalah mode pakaian maka langue adalah pada tataran komunikasi pakaian, dan parole pada tataran komunikasi dengan kata-kata. Sehingga langue dan parole menganalisis unsur-unsur yang berupa kata, tata bahasa, pilihan kata, dan struktur kalimat. Langue dan parole menjelaskan tentang makna-makna kebahasaan dan content secara harfiah, yaitu dengan menjelaskan arti kata secara leksikal atau arti yang mendasar dari Syi'ir Tanpa Waton.
1. Pesan dakwah ketauhidan, permohonan ampun pada Allah serta penghormatan dan sanjungan pada Nabi Muhammad saw.

Pada bait ke-1 dan ke-2 pada syi'ir ini membahas tentang permohonan ampun atas dosa dan sekaligus menunjukkan bahwa hanya pada Allah tempat segala sanjungan dan permohonan, untuk bisa melaksanakan apa yang menjadi permohonannya maka dilakukan sanjungan kepada Rasul Muhammad sebagai orang yang dianggap kekasih Allah yang bisa memberikan jalan menuju keselamatan serta sanjungan pada seseorang yang memiliki budi pekerti luhur. Pada bait ke-1 dan ke-2 ini terlihat adanya perpaduan keterhubungan antara Sang Pencipta dengan Rasul sebagai utusan untuk memberikan teladan atas pesan-pesan yang bisa memberikan keselamatan. Pada kata "semoga" serta kata "keselamatan" menunjukkan bentuk parole yang menjelaskan atas kalimat wahai utusan Allah yang bisa dipahami bahwa Rasullulah sebagai utusan Allah senantiasa diharapkan mendapatkan keselamatan dari Allah.

Pada baris ke-1 dalam bait ke-2 terjadi suatu keserasian atas langue dan parole-nya. Baris ke-2 tetap sama diawali dengan bentuk kalimat seruan yang diawali dengan huruf ( يا ) yang artinya wahai namun pada baris kedua ini dipadukan dengan kata yang berbudi luhur dan bermartabat tinggi. Jika dilihat dengan kaitan pada baris ke-1 kata "berbudi luhur" dan "bermartabat tinggi" menunjuk pada utusan Allah tersebut. Tetapi bila dilihat dengan awalan kata "wahai," bait kedua bisa diartikan objek sendiri. Baris ketiga bentuk kata (يا ) terletak sesudah kata عطفة yang memiliki arti belas

\footnotetext{
${ }^{51}$ Sobur, Semiotika Komunikasi., 48.
} 
kasih, cinta. Menjadi "belas kasihmu wahai pemimpin lingkungan sekitar/tetangga" ( (ب) Pada baris keempat diawali dengan kata panggilan wahai (ب ) kemudian disambung dengan kata "ahli dermawan" dan "pemurah hati." Apabila dilihat pada struktur kalimat tersebut bentuk panggilannya semua di atas menjelaskan mengenai utusan Allah yang disebut dengan Rasul. Seorang rasul memiliki budi yang luhur, bermartabat tinggi, kasih sayang, dermawan, murah hati, dan sebagai pemimpin di lingkungan sekitar.

Pada bait ke-3 di atas, struktur kalimat tiap baris menggunakan bahasa Jawa. Agaknya struktur bahasa Jawa dapat mengambil sebuah peranan yang serasi baik pada bentuk langue maupun parole dengan beberapa kata dalam bahasa Arab yang masuk ke dalam struktur kalimat tersebut. Proses masuknya sebuah bentuk kata dalam bahasa Arab ke dalam bahasa Jawa serta dapat dengan teratur dan terstruktur dengan baik. Menunjukkan ada perpaduan langue dan parole yang memiliki kesamaan jenis pada struktur kalimatnya yang terangkai dalam struktur komunikasi beda budaya tersebut serta dalam lintas peradaban pada perspektif genomiknya yaitu perkembangan garis genetik secara relevan melahirkan bahasa yang memiliki kemiripan tinggi. Misal syi'iran diambil dari kata dasar "syi'ir", "rohmat" dan "nikmat". Kata syi'ir dari kata syi'ru (الثعرُ,) dalam bahasa Arab. Kemudian diserap ke dalam bahasa Jawa menjadi "syi'ir". Secara harfiah syi'ir memiliki makna syair. Istilah berikutnya adalah "rohmat". Kata rohmat berasal dari bahasa Arab rahima (رحم) - yarhamu (يرحم) rohmatan (رحمة ) yang berarti rahmat, kemurahan, belas kasih. Sedangkan nikmat berasal dari kata ni'mah ( نعمة ) yang memiliki makna keberkahan, anugerah. Beberapa contoh kata tersebut yang masuk dalam serapan kata menunjukkan bahwa bahasa memiliki pola-pola dan cara-cara berkembang secara genetik dengan tiga cara yakni kolonisasi, percabangan, dan substitusi.

Setelah memahami dalam kegiatan langue dan parole-nya yang memiliki kesesuaian dalam keduanya maka pada aspek signife dan signifiant-nya dalam bait syi'ir ke-1 dan ke-2 yaitu:

Aku memohon ampun ya Allah Maha Penerima Taubat

Aku memohon ampun ya Allah dari segala dosa Tambahkanlah kepadaku ilmu yang bermanfaat Berikanlah aku amalan yang baik

Wahai utusan Allah, semoga keselamatan tetap padamu

Wahai yang berbudi luhur dan bermartabat tinggi

Rasa kasihmu wahai pemimpin tetangga/lingkungan sekitar Wahai ahli dermawan dan pemurah hati

Bait pertama Syi'ir Tanpa Waton di atas memiliki signifie (penanda) dan signifiant (pertanda) bunyi kata pertama yaitu Allah yang menonjol yang diawali dengan struktur kalimat rintihan atau keluhan berupa panjatan doa ditujukan pada Allah. Maka Allah sebagai signifiant (pertanda) memiliki sebuah konsep makna tertentu. Allah dipahami sebagai sebuah sesembahan atau Tuhan di atas sesembahan dan Tuhan-tuhan yang lain yang disembah dan diibadahi. Dia memiliki sifat dan nama-nama yang baik yang senantiasa melekat pada diri-Nya, Yang Menciptakan, Yang Mengadakan, Yang Membentuk rupa, Yang Mahaperkasa, Mahabijaksana. Maka pada baris pertama dan kedua Allah dipahami sebagai segala hal yang memiliki kekuatan hingga layak Dia 
dipandang sebagai sesuatu yang mampu menerima taubat atas dosa yang dilakukan manusia. Kedua signifie (penanda) "ilmu" yang dianggap sebagai sesuatu yang bermanfaat maka signifiant (pertanda) "ilmu" memilki suatu konsep secara alami mampu memberikan kemanfaatan dirinya. Konsep 'ilmu' dipahami sebagai hasil suatu proses dari bekerjanya panca indra dalam melihat realitas kemudian diproduksi pada daya pikir manusia menjadi sesuatu yang bisa digunakan baik dalam lapangan empiris maupun dalam lapangan rasional. Hasil proses tersebut didasarkan pada data-data yang telah diturunkan Allah baik data yang tersurat maupun data yang tersirat. Maka pertanda "ilmu" dalam baris ketiga tersebut diperlukan serta diharapkan bisa bertambah untuk bisa bermanfaat dalam dirinya. Ketiga pada signifie (penanda) "amalan", bunyi ini didasarkan atas pangkal kata amal dengan akhiran -an. Dalam tanda bahasa Arab bentuk ini biasa disebut dengan masdar bentuk kata yang tidak terikat dengan zaman ataupun waktu. Sedangkan signifiant (pertanda) pada kata "amalan" jika dilihat pada makna konotatifnya berarti sebuah bentuk perbuatan. Perbuatan didorong oleh motif. Adapun motif dibentuk dari pengetahuan dan pengalaman. Dorongan motif seseorang bisa baik maupun buruk. Sedangkan permohonan amalan dalam baris keempat ini menghendaki amalan yang baik. Makna amalan baik ini amalan yang seimbang menurut kemampuan sehingga tidak merasa dibebani di luar kemampuannya.

Pada bait kedua ini ditemukan sebuah signifie (penanda) yang kuat yaitu Rasul. Bunyi "Rasul" diiringi dengan tanda "Wahai" yang menunjukkan pada suatu bentuk panggilan atau bentuk memanggil. Yang dipanggil adalah Rasul atau utusan, maka bentuk signifiant (pertanda) atas utusan menunjukkan seseorang yang sedang mengemban sebuah tanggung jawab serta mempunyai sifat-sifat yang luhur dan berbudi tinggi serta dermawan. Adapun makna utusan dalam baris pertama tersebut disandingkan dengan Allah, sehingga memiliki bentuk kekhususan atau spesifik bahwa dia adalah utusan Allah yang membawa amanat serta tugas dari-Nya khususnya dalam menyampaikan petunjuk risalah agama.

\section{Pesan dakwah tentang sifat-sifat manusia} yang terkadang tidak sesuai dengan ajaran Islam

Pada bait ke- 5 dan ke- 6 syi'ir ini membahas tentang sifat-sifat manusia yang hendaknya ditinggalkan. Sifat-sifat ini merupakan sifat yang bertentangan dengan nilai-nilai Islam, seperti: sombong, iri hati, dan dengki. Sifatsifat ini ditekankan dalam bentuk kode konotatif yang mencoba menyindir pendengar tentang karakter yang sering ditunjukkan oleh manusia. Pada aspek parole-nya (bahasa yang khas digunakan oleh penulis syi'ir) ditemukan bahwa dalam menggambarkan pesan dakwah tersebut menggunakan pilihan kata dalam satu kalimat yang satu kalimat bisa bertentangan. Misalnya: "Akeh kang apal Qur'an Haditse, Seneng ngafirke marang liyane". Pilihan kata-kata ini menunjukkan sindiran bagi umat muslim yang memiliki karakter-karakter yang bertentangan dengan ajaran Islam meskipun seakan-akan memiliki kelebihan menghafal Alquran.

Tanda parole yang lain yang terdapat pada bait ke- 5 dan ke- 6 antara lain: penggunaan kata-kata: "apal qur'an lan hadise", "irimeri", "seneng ngafirke liyane, kafire dewe dak ditekke", "nafsu angkara" yang mana pada umumnya orang menggunakan istilah: hafal Alquran dan Hadis", "iri dan dengki", 
"suka mengafirkan orang lain, sedangkan kekafirannya sendiri tidak dihiraukan", "nafsu syahwat". Namun, penulis syi'ir lebih memilih menggunakan rangkaian kalimat dengan bahasa Jawa yang itu khas diproduksi oleh penulis sendiri dan sesuai dengan langue masyarakat yang mendengarkan.

Setelah memahami kekhasan bahasa yang digunakan oleh penulis syi'ir. Kita juga dapat mengetahui makna pesan dakwah yang terkandung dengan melihat dari pilihan bahasa yang digunakan. Syi'ir ini menggunakan pertanda (signifiant) dalam bentuk kalimat-kalimat dengan bunyi yang ditekankan dengan akhiran bunyi huruf yang sama yaitu: eeee, aa, oo. Selain itu pertanda (signifiant) ditunjukkan melalui pilihan kata berbahasa Jawa yang digunakan.

Akeh kang apal Qur'an Haditse

Seneng ngafirke marang liyane

Kafire dhewe dak digatekke

Yen isih kotor ati akale2x

Gampang kabujuk nafsu angkara

Ing pepahese gebyare ndonya

Iri lan meri sugihe tanggo

Mula atine peteng lan nistho $2 x$

Pertanda pada bait kelima baris pertama "akeh kang apal Qur'an haditse" memiliki makna (signifie) menunjukkan banyak orang Islam saat ini yang hafal dan menguasai terhadap Alquran hadis. Pertanda "Alquran" dipahami sebagai kitab yang tidak ada keraguan di dalamnya sebagai petunjuk bagi orang-orang muttaqin. ${ }^{52}$ Sedangkan pertanda "hadis" dimaknai sebagai segala

\footnotetext{
52 Departemen Agama RI., Alquran dan Terjemahannya, QS. 2:2

53 Fatchur Rahman, Ikhtisar Musthalahul Hadits (Bandung: Al-Ma'arif, 1970, cet ke 12), 20.
}

sesuatu yang disandarkan pada Nabi Muhammad saw. baik berupa perkataan, perbuatan, pernyataan (taqrir) dan yang sebagainya. ${ }^{53}$ Sedangkan penanda "seneng ngafirake marang liyane" mengandung pertanda "seneng" (suka) menunjukkan makna perbuatan yang didasari oleh kegembiraan sedang pertanda "ngafirake" memiliki makna menuduh orang atau kaum melakukan tindakan pengingkaran terhadap kebenaran atau menutupi kebenaran dalam hal ini Alquran dan hadis, adapun pertanda "marang liyane" menunjukkan bahwa kegiatan mengafirkan tersebut terhadap orang lain yang dipandang memiliki konsep ajaran yang salah (bertentangan dengan Alquran dan hadis).

Pada baris ketiga terdapat pertanda "kafire dhewe dak digateake" makna pertandanya adalah bahwa tindakan yang menunjuk seseorang atau kaum yang dikatakan kafir tersebut tidak dijadikan evaluasi atau introspeksi diri bahwa bisa jadi sifat atau tindakan kafir itu adalah milik dirinya sendiri namun dia atau kaum tidak memperhatikan. Baris keempat berbunyi pertanda "yen isih kotor ati akale", makna pertanda "yen" yang memiliki penanda jika mengandaikan adanya tindakan bertolak belakang pada tindakan yang sebelumnya dikemukakan dan bisa juga menjadi prasyarat terhadap tindakan yang lain, "isih kotor" menunjukkan masih belum bersih atau belum suci, "ati akale" pertanda "ati" dalam bahasa Arab biasa diistilahkan dengan qolbun ( قلب memiliki makna hati yang lembut, ${ }^{54}$ Bisa pula hati yang keras..$^{55}$ Bila melihat bahwa hati bisa memiliki

\footnotetext{
54 Departemen Agama RI., Alquran dan Terjemahannya, QS. 26:89.

55 Departemen Agama RI., Alquran dan Terjemahannya, QS. 3:159.
} 
kelembutan sekaligus keras dapat dipahami bahwa pertanda ati juga bisa dipahami merupakan bagian dari fungsi jiwa. Pertanda "akale" dimaknai sebagai akalnya, berasal dari kata ( عقل ) yang memiliki arti mengikat, memahami, mengerti. ${ }^{56}$ Makna akale juga bisa dipahami sebagai salah satu fungsi jiwa yang mampu untuk mengikat serta memahami atas realitas yang ditangkap oleh indrawi dan mampu untuk memikirkan atas sesuatu sehingga dapat menghasilkan pengetahuan baru. Maka pertanda pada baris keempat menunjukkan bahwa apabila salah satu fungsi jiwa yang digunakan untuk merasa maupun berpikir masih belum bersih orang tersebut mudah sekali menilai kafir pada orang yang lain. Sehingga dilihat dari signified dan signifier pada bait ini menunjukkan bahwa "yen isih kotor ati akale" memiliki makna bahwa jiwa yang dimiliki oleh orang yang suka mengafirkan adalah masih kotor, tidak bersih sebagaimana jiwa yang baik yang diajarkan oleh Alquran dan hadis.

Bait ke- 6 baris pertama pada bait syi'ir ini memuat penanda "gampang kabujuk" makna pertandanya adalah merujuk pada orang yang mudah terbujuk atau dapat terpengaruh secara gampang tidak melewati pertimbangan yang kuat, "nafsu angkara" penanda nafsu (نفس ) serapan dari bahasa Arab sedang angkara serapan dari bahasa Jawa yang memiliki arti jahat, tamak. ${ }^{57}$ Penanda nafsu angkara merupakan satu frasa yang memiliki arti dorongan jahat atau tamak. Istilah "nafsu angkara" memiliki pertanda yang mirip dengan nafsu syahwat yang lebih mengarah pada kecintaan terhadap segala perhiasan dunia. ${ }^{58}$ Makna

56 Atabik Ali, Ahmad Zuhdi Muhdhlor, Kamus Kontemporer Arab-Indonesia, (Yogyakarta: Multi Karya Grafika Pondok Pesantren Krapyak, 1996), 1307. pertanda tersebut sesuai dengan rangkaian bait syi'ir pada baris kedua yang berbunyi "ing pepahese gebyare donya" (dalam gemerlapnya perhiasan dunia). Pada baris ketiga terdapat penanda "iri lan meri" diterjemahkan dengan iri dan dengki, makna iri dan dengki lebih pada suatu dorongan sifat yang telah tertanam dan yang ada dalam diri manusia, hanya saja sifat tersebut memuat kecenderungan yang merugikan, pertanda ini sesuai dengan kelanjutan pada baris yang sama yaitu "sugihe tangga" (kekayaan tetangga), makna kekayaan tetangga menunjukkan bahwa sifat iri dan dengki tersebut menghendaki untuk bisa menyamai bentuk kekayaannya dengan berbagai jalan yang dilakukan meskipun jalan tersebut salah menurut agama, misalnya dengan jalan korupsi atau menipu dalam membangun kekayaannya. Kemudian ditutup dengan penanda pada baris keempat dengan bunyi "Yen isih kotor ati lan pikire" keadaan sebuah hati dan akal yang belum jernih akibat dari pengaruh nafsu syawat yang berupa kecintaan terhadap halhal keduniawian, sehingga hati dan akalnya menjadi kotor dan gelap olehnya.

Dari pemaparan di atas pesan dakwah dalam bait kelima dan keenam jika ditinjau dari aspek penanda (signifier) dan makna (signifie) tandanya menunjukkan bahwa banyak orang Islam yang memiliki hafalan Alquran atau bahkan hadis namun memiliki karakter yang bertentangan dengan nilainilai (ajaran) yang terkandung dalam Alquran dan hadis itu sendiri. Karakter yang sering dijumpai meliputi fenomena seharihari yang sering ditunjukkan oleh beberapa umat Islam saat ini seperti: suka

\footnotetext{
57 Maheswara, Kamus Jawa., 18.

58 Departemen Agama RI., Alquran dan Terjemahannya, QS. 3:14.
} 
mengafirkan orang/kelompok lain yang memiliki pemahaman berbeda dengan yang diyakini, yang suka iri dan dengki pada harta kekayaan yang dimiliki tetangganya.

\section{Pesan Dakwah untuk senantiasa mengkaji, menguatkan iman serta berhati baik.}

Pada syi'r bait ke-7 dan ke-8, pada struktur kalimat yang terdapat di bait ke-7 baris ke tiga dijumpai kembali adanya parole dalam bahasa Arab yaitu kata Tauhid (توحيد) : bentuk masdar dari وحَّ) berarti pengesaan, penyatuan. Dan kata liman (إيمان) yang berarti iman, kepercayaan. Bait ke-7 dimulai dengan struktur pesan menggunakan kata "ayo" yang berarti sebuah ajakan yang disampaikan untuk para saudara (sedulur) supaya tidak melupakan wajibnya mengkaji (mengkaji agama) bersama aturannya (baris pertama dan kedua) fungsinya untuk mempertebal iman (kepercayaannya) dan tauhid (pengesaan, penyatuan) sehingga bisa menjadi baik sebagai bekal kemuliaan saat matinya (baris ketiga dan keempat). Bila dilihat dalam rangkaian kalimatnya terlihat adanya kesinambungan dalam struktur langue maupun parole-nya dalam keseluruhan baris.

Pada bait ke-8 terdapat bentuk parole serapan kata dalam bahasa Arab yaitu "Sholeh" berasal dari kata sholihun (صالح) yang secara harfiah berarti yang baik, bagus. Kemudian kata ma'rifat ( معرفة) yang juga secara harfiah diartikan dengan pengetahuan, konsepsi. Selain itu ada kata thoriqot ( طريقة ) diartikan secara harfiah dengan cara, metode, prosedur, proses, mode, sistem juga bisa diartikan dengan lantaran, wasilah, juga bisa diartikan dengan sekte, mahzab, doktrin. Adapula kata hakikat ( حقيقة ) secara harfiah diartikan dengan beberapa istilah di antaranya kebenaran, keabsahan, kenyataan, esensi, dan substansi.

Pada baris pertama struktur kalimatnya dimulai dengan menunjukkan sebuah identitas yang berkaitan dengan perilaku baik atau bagus yang berkesesuaian dengan hatinya, sebab sudah lengkap ilmunya (baris pertama dan baris kedua). Pada baris ketiga dimulai dengan jalan thoriqot (agaknya ini istilah teknis khusus) yang saya artikan dengan wasilah atau perantaraan dan makrifat (sebuah konsepsi).

Baris keempat menjadi kelanjutan dari baris ketiga yaitu suatu kebenaran (hakikat) juga mampu meresap pada perasaan. Apabila kalimat pada baris ketiga dan keempat dipahami menjadi jalan wasilah dan sebuah konsep (makrifat) adalah kebenaran yang mampu meresap pada perasaan.

Struktur pada bait ke-8 ini antara baris pertama dan baris kedua berbeda struktur dengan baris ketiga dan keempat dalam bentuk langue dan parole-nya. Sebab yang pertama dan kedua menunjukkan identitas sifat dengan bantuan ilmu adapun yang ketiga dan keempat menawarkan atas jalan lain untuk mampu menuju pada sebuah jalan konsep yang mengarah pada suatu kebenaran sehingga mampu untuk yakin dan mendalam pada perasaan bagi yang mengambil jalan konsep tersebut.

Bait ke-7 berisi penanda tentang ajakan supaya tidak melupakan keharusan mengkaji beserta aturan dan metodologinya dalam bunyi "Ayo sedulur ja nglalekake wajibe ngaji sak pranatane", dalam baris ini ditemukan penanda "ngaji" yang dalam maknanya mengkaji atau mempelajari aturan atau mempelajari syariat, tasawuf, 
atau ketuhanan yang telah disebutkan di atas dengan segala pranatanya atau metodologi dan isinya serta fungsinya adalah untuk mempertebal iman tauhidnya. Makna iman tauhidnya menunjukkan pada kepercayaan yang tunggal terhadap konsep ketuhanannya. Dengan demikian diharapkan dapat memancarkan pada perilaku yang benar dan bernilai sebagai bekal kemuliaan dalam matinya atau meninggalnya dikemudian hari.

Bait ke-8 syi'ir diawali dengan penanda "kang aran sholeh bagus atine" pertanda ini memiliki makna orang yang dianggap saleh memiliki "ati" yang bagus. Pertanda "sholeh" memiliki makna perilaku atau tindakan yang baik (saleh), kata sholeh diambil dari serapan bahasa Arab sudah menjadi makna lazim dalam bahasa Jawa yang bisa dimaknai suatu tindakan yang baik. Makna tindakan baik di antaranya adalah beriman pada Allah, pada hari kemudian serta senantiasa melakukan perbuatan yang berguna sehingga tidak akan merasakan kekhawatiran dalam hidupnya. Sehingga yang dikatakan tindakan saleh senantiasa memiliki ukuran-ukuran tertentu yang bisa dipertanggungjawabkan semisal ukuran tindakan saleh adalah beriman pada Allah berarti dia mampu untuk membuktikan perihal keberadaan Allah dengan argumen logis dan rasional sehingga betul-betul tertanam keimanan yang benar dalam dirinya. Oleh karena itu tindakan saleh mampu berpengaruh pada sisi kejiwaan (ati/qolbun) yang bagus. Kalimat penanda "karana mapan sari ngelmune" memiliki pertanda dan makna bahwa seseorang yang baik atau saleh dan hatinya baik memiliki sebab telah mapan, makna "mapan" dapat dipahami telah menguasai dan memahami substansi dari pengetahuan yang telah dimiliki. Makna ini dapat dipahami bahwa mereka yang telah mampu untuk memahami secara filosofis dari suatu ilmu akan mampu memberikan kebaikan perilaku serta ketenangan dan ketenteraman hati. "Laku tariqot lan ma'rifate" penanda ini memiliki makna melakukan kerja atau tindakan tarekat dan makrifatnya, dua penanda ini yaitu tarekat dan makrifat lebih dipahami sebagai sebuah langkah dan tahapan dalam metode tasawuf, begitu pula dengan penanda hakikat yang juga memiliki makna sebagai jalan tasawuf yang dilakukan. Ketiga komponen tersebut hendaknya mampu untuk ditanamkan berdiri dalam rasa dan perasaannya.

\section{Kesimpulan}

Berdasarkan pada analisis di atas, setelah penulis menganalisis Syi'ir Tanpo Waton karya K.H. Muhammad Nizam As-Shofa (Gus Nizam) maka dapat disimpukan bahwa, pertama, pemahaman dengan pendekatan content mengungkapkan adanya simbolsimbol tanda dalam bentuk parole (bunyi) dalam pertanda dengan bentuk bahasa Jawa yang mampu menyerap dalam pertanda bahasa Arab misalnya roh, ilmune, rasule, kafir yang memiliki sifat penanda dengan jenis kemiripan yang sama. Hal ini menujukkan bahwa ada segi keunikan dan keuniversalan sebuah tanda dalam bingkai pesan dakwah lintas kultural dalam bentuk etnografi yang berbeda dilihat dari aspek semiotik linguistiknya. Serta terdapat penonjolan-penonjolan dan penekananpenekan signife (penanda) maupun signifient (pertanda) yang dihubungkan dengan kecenderungan konsep keagamaan Islam di masyarakat Jawa. Hal itu dihubungkan pula dengan tatanan struktur 
masyarakat yang memahami konsep agama secara teks, cenderung mistis, sederhana, dan mudah namun tanpa meninggalkan kekhasan dalam penanda dari bahasa Arab misalnya: Allah, Pengeran, Gusti, kafire, Nabi Muhammad, suwarga. Dan bentuk-bentuk titik tekan kuat dalam tanda kritik terhadap mereka yang suka melakukan penilaianpenilaian negatif dengan penanda "seneng ngafirke" (suka mengafirkan) tapi kafirnya sendiri tidak diperhatikan.

Kedua, melalui konvensi simbol-simbol Syi'ir Tanpo Waton tersebut, menunjukkan adanya kandungan pesan dakwah yang mendalam yang terungkap melalui analisis semiotika strukturalis. Pesan tersebut tersebar di tiap bait dan baris syi'ir. Pesan pertama yaitu pesan dakwah ketauhidan, permohonan ampun pada Allah serta penghormatan dan sanjungan pada Nabi Muhammad saw. Bagian tersebut menunjukkan sifat-sifat Allah yang menjadikan Allah sebagai satu-satunya yang layak disembah dan mampu menerima taubat, serta sifat-sifat Rasul sebagai utusan Allah yang berbudi luhur, bermartabat tinggi, dan dijadikan pemimpin. Pesan pertama terdapat pada bait pertama, kedua dan ketiga.

Pesan kedua yaitu tentang sifat-sifat manusia yang terkadang bertentangan dengan ajaran Islam. Hal tersebut terdapat pada bait kelima dan keenam yaitu menunjukkan sifat-sifat yang sering dilakukan namun bertentangan dengan nilai-nilai Islam dan baiknya ditinggalkan manusia, di antaranya adanya banyak orang Islam yang memiliki hafalan Alquran atau bahkan hadis namun mudah mengafirkan orang lain, suka iri dan dengki pada harta kekayaan tetangga, tanpa melakukan instrospeksi terhadap dirinya sendiri

Pesan ketiga, senantiasa memuji Allah dan mencari ilmu ajaran Islam bukan hanya pada syariatnya saja. Hal tersebut terdapat pada bait ketiga dan keempat. Bagian tersebut mengandung makna kepada Tuhan Allah adalah tempat kita memberikan penghormatan dan pujian siang dan malam hingga kita mendapat rahmat. Untuk mendapatkan rahmat Allah dilakukan bukan hanya dengan membaca dan menghafal syariat namun harus mempelajari pengetahuan terkait lainnya untuk dapat mengamalkannya dengan baik.

Pesan keempat, ajakan untuk senantiasa mengkaji, menguatkan iman dan berhati baik. Ditunjukkan pada bagian syi'ir bait ketujuh dan kedelapan. Bahwa dalam mengkaji agama haruslah mempelajari dengan benar yaitu dengan mengkaji metode yang benar, isi dan fungsi secara mendalam atau filosofis sehingga dapat memperkuat iman. Dalam mengkaji agama terdapat tahapan mulai dari tarekat, makrifat, hingga hakekat, semakin mendalam yang dipelajari dan dikaji maka akan semakin terbangun perasaan yang mendalam terhadap pengetahuan, semakin mampu menguasai pengetahuan yang dimiliki dan berbaik hati kepada sesama. 


\section{Bibliografi}

Ali, Atabik, dan Ahmad Zuhdi Muhdhlor. Kamus Kontemporer Arab-Indonesia. Yogyakarta: Multi Karya Grafika Pondok Pesantren Krapyak, 1996.

Alwasilah, Chaedar. A. Beberapa Madhab dan Dikotomi Teori Linguistik. Bandung: Angkasa, 1985.

Berita Surat Kabar, Harian Bangsa, Jum'at 19 Agustus 2011.

Bertens, K. Filsafat Barat abad XX Jilid II Perancis. Jakarta: Gramedia, 1985.

Blacburn, Simon. Kamus Filsafat. DIterjemahkan oleh Yudi Santoso, Jakarta: Penerbit Kencana, 2013.

Chaer, Abdul. Linguistik Umum , Jakarta: Rineka Cipta, 2002.

Endaswara, Suwardi. Metodologi Penelitian Sastra Epistemologi, Model, Teori dan Aplikasi. Yogyakarta: CAPS, 2013.

Hidayat, Asep Ahmad. Filsafat Bahasa Mengungkap Hakekat Bahasa, Makna dan Tanda. Bandung: Rosdakarya, 2009.

Jorgensen, Marianne W dan Louise J. Philips. Analisis Wacana Teori dan Metode. Diterjemahkan oleh Imam Suyitno dkk. Yogyakarta: Pustaka Pelajar, 2007.

Kaelan M.S, Filsafat Bahasa Semiotika dan Hermeneutika. Yogyakarta: Paradigma, 2009.

Kuswarno, Engkus. Metode Penelitian Komunikasi Etnografi Komunikasi. Bandung: Widia Padjajaran, 2011.

Luxemburg, Jan van et.al, Pengantar IImu Sastra. diterjemahkan oleh Dick Hartono, Jakarta: Gramedia, 1992.

Maheswara, Majendra. Kamus Jawa Indonesia. Yogyakarta: Pustaka Mahardika, tt.

Moh. Ali Aziz, Ilmu Dakwah, ed revisi, Jakarta: Kencana, 2016.

Morissan. Teori Komunikasi Individu hingga Massa. Jakarta: Kencana Prenada Media Group, 2013.

Munawir A. W, dan Muhammad Fairus. Kamus Al-Munawir Indonesia-Arab. Surabaya: Pustaka Progresif, 2007.

Nizam, Gus. "Syi'ir Tanpo Waton," Surat Kabar Media Umat, Minggu ke III dan Ke IV 2014, 16 Rajab-Sy'ban $1435 \mathrm{H}$.

Rahman, Fatchur. Ikhtisar Musthalahul Hadits. Bandung: Al-Ma'arif, 1970.

Saputri, Nikken Derek. "Syi'ir Tanpa Waton (Kajian Semiotik)," Sutasoma: Journal of Javanese Literature, Vol. 2, no. 1, (2013).

Saussure, Ferdinand de. Pengantar Linguistik Umum. Diterjemahkan oleh Rahayu S Hidayat. Yogya: Gajah Mada University Press. 1988.

Sobur, Alex. Semiotika Komunikasi. Bandung: Remaja Rosda Karya, 2004.

Wedemeyer, Christian K. "Beef, Dog, and Other Mythologies: Connotative Semiotics in Mahayoga Tantra Ritual and Scripture," Journal of the American Academy of Religion, Vol. 75, no. 2, (2007): 383-417.

Zaimar, Okke K. S. Semiotika Dalam Analisis Karya Sastra. Depok: Komodo Baokks, 2014. 
Mohammad Fajar Amertha

120 | INTELEKSIA - Jurnal Pengembangan IImu Dakwah 
Analisis Pesan Dakwah Syiir Tanpo Waton Pendekatan Semiotik Ferdinand de Saussure 